\title{
Analyzing effects of service encounter quality on customer satisfaction in banking industry
}

\author{
Hossein Gazor $^{\mathrm{a}^{*}}$, Babak Nemati $^{\mathrm{a}}$, Amir Ehsani $^{\mathrm{a}}$ and Kianoush Nazari Ameleh
}

${ }^{a}$ Researcher of Islamic Azad University, Kashmar Branch, Kashmar, Iran

${ }^{b}$ Department of Management and Accounting, Allameh Tabataba'i University, Tehran, Iran

\begin{tabular}{l}
\hline A R T I C L E I N F O \\
\hline Article history: \\
Received August 28, 2011 \\
Received in Revised form \\
November, 14, 2011 \\
Accepted 19 November 2011 \\
Available online \\
22 November 2011 \\
\hline Keywords: \\
Service encounter quality \\
Service quality \\
Customer satisfaction \\
Customer loyalty
\end{tabular}

\section{A B S T R A C T}

Service quality represents a modern approach for quality in enterprises and organizations and serves the development of a truly customer-focused management and culture. Measuring service quality offers an immediate, meaningful and objective feedback about clients' preferences and expectations. In this paper, we study the relationship between customer perceptions from service encounter quality and loyalty of customer to organization and employees. The proposed study is implemented for banking sector in Iran using SERVQUAL factors and considers various factors influencing the quality of service. The results of the survey indicate that service quality systems, customer satisfaction are the most desirable factors based on the feedback we received from the customers. In addition, response to customers and loyalty to employees, service encounter quality, service and loyalty to organization, arrangements are in the next levels, respectively.

\section{Introduction}

Service quality has been one of the most frequently used devices for measuring the impact of various factors in different businesses such as banking industry (Kang \& James, 2004). One important change in global economy is the significant growth of service industry especially in developing countries. Customer service is a distinct component of both product and service sectors and with the developments in information technology many business find demanding and knowledgeable customers. The worldwide trend towards service quality was initiated in early eighties when businesses realized that a quality product, in itself, is not guaranteed to maintain competitive advantage (Van der Wal et al., 2002).

Many researchers recognized that service quality is able to empower an organization and create competitive advantage (Moore, 1987; Lewis, 1989). Quality of services' content can be the distinction

* Corresponding author. Tel: +989124354291, fax: +981925222099

E-mail addresses: hossein.gazor@yahoo.com (H. Gazor) 
between success and failure in both service and manufacturing organizations. Service quality, customer satisfaction and customer value are the main concern of both manufacturing and service organizations in the increasingly intensified competition for customers in today's customer-centered era (Wang et al., 2004).

\section{Literature review}

\subsection{Service quality}

Service quality is known as the basis of multiple dimension studies (Gronroos, 1982, 1990; Parasuraman et al., 1985), there is no general agreement as to the nature or content of the dimensions (Brady \& Cronin, 2001). Lehtinen and Lehtinen (1982) defined service quality in terms of physical quality, interactive quality and corporate (image) quality. Physical quality is associated with tangible aspects of the service. Interactive quality involves the interactive nature of services and refers to the two-way flow, which occurs between the customer and the service provider, or his/her representative, including both automated and animated interactions. Corporate quality refers to the image attributed to a service provider by its current and potential customers, as well as other publics. They also suggested that, when compared with the other two quality dimensions, corporate quality tends to be more stable over time.

A common definition of service quality is that the service should correspond to the customers' expectations and satisfy their needs and requirements (Edvardsson, 1998). Therefore, many organizations extremely consider service quality to obtain their customers' satisfaction and loyalty. In some manufacturing industries, "service quality" is considered as more important order winner than "product quality" (Ghobadian et al., 1994). Service quality improvements lead to customer satisfaction and cost management, which result in improved profits (Stevenson, 2002). The International Standardization Organization (ISO) defines a service as a part of the total production concept (Edvardsson, 1998). Services are often "invisible" and thus difficult for the supplier to explain and for the customer to assess.

Edvardsson (1998) believes that the concept of service should be approached from a customer perspective. It is the customer's total perception of the outcome, which is "the service". It forms the perception of quality and determines whether a particular customer is satisfied or not. Customers have different values and different grounds for assessment, they may perceive one and the same service in different ways. Measuring the quality of service outputs is often more difficult than measuring the quality of a good quality service, because services are abstract rather than concrete, transient rather than permanent, and psychological rather than physical (Meredith \& Shafer, 2002).

\subsection{Customer satisfaction and loyalty}

There are tremendous efforts for measuring customer satisfaction and service quality and there are literally various methods to define customer satisfaction and service quality. Yazdanpanah and Gazor (2012), in assessing success factors of electronic customer relationship management (ECRM) system mentioned that proper ECRM could increase customer satisfaction and improve services. Oliver (1997) defined satisfaction as "the consumer's fulfillment response, the degree to which the level of fulfillment is pleasant or unpleasant”. Zeithaml and Bitner (2000) defined customer satisfaction as the “customers' evaluation of a product or service in terms of whether that product or service has met their needs and expectations". 
Parasuraman et al. (1988) conceptualized customer evaluations of overall service quality as the gap between expectations and perceptions of service performance levels. They developed the SERVQUAL instrument for measuring service quality offered by service firms. Customer satisfaction, which refers to "the summary psychological state resulting when the emotion surrounding disconfirmed expectations is coupled with the consumer's prior feelings about the consumption experience" (Oliver, 1981), is often considered as an important determinant of repurchase intention (Liao et al., 2009) and customer loyalty (Eggert \& Ulaga, 2002). It is the most important research topic in the information system area (Au et al., 2008).

Customer satisfaction reflects the degree of a customer's positive reaction for a service provider in a bank context, it is necessary for service providers (bank) to recognize the customer's vision of their services. A high level of customer satisfaction can have a positive impact on customer loyalty (Deng et al., 2010). If a service provider can satisfy the needs of the customer better than its competitors, it is easier to create loyalty (Oliver, 1999). Fornell (1992) stated that high customer loyalty is mainly caused by high customer satisfaction. Clarke (2001) proposed that effective satisfaction must be able to create loyalty amongst customers. Previous studies have demonstrated that customer satisfaction positively affects customer loyalty (Cho et al., 2008) or negatively affects switching intention (Walsh et al., 2006).

\subsection{The SERVQUAL instrument}

The term of service quality has become a controversial discussion in terms of definition as well as measurement since there is not a crystal clear definition for this phrase. During the past few years, SERQUAL has become the most popular method for assessing service quality (Van der Wal et al., 2002; Wisniewski, 2001; Harvey, 1998; Curry \& Sinclair, 2002; Van derWal et al., 2002; Gabbie \& O’Neill, 1997). Parasuraman et al. (1985) is believed to be the first who introduced the conceptual framework for the SERVQUAL model to measure consumer perceptions of service quality and later refined the model. The model was initially developed for financial services sector and it has been used for other sectors such as telecommunications, healthcare and hospitality (Curry \& Sinclair, 2002; Van der Wal et al., 2002; Sultan \& Simpson, 2000; Saleh \& Ryan, 1991).

SERVQUAL considers service quality as the disparity between the expectations and perceptions of the customer, and the service actually delivered (Curry \& Sinclair, 2002; Ninichuck, 2001). The Parasuraman et al. (1988) study modified the model to consider five dimensions: tangibles, reliability, responsiveness, assurance, and empathy, which are representative for performance standards, expertise and physical elements of the facility, employees' willingness to assist in a timely manner with their knowledge, and sensitivity (Kang, 2006). Although there is a general agreement that service quality has many dimensions (Gronroos, 1982, 1990; Berry et al., 1985; Parasuraman et al., 1985), there is not a precise definition on the exact nature and content of these dimensions (Brady \& Cronin, 2001). Lehtinen and Lehtinen (1982) defined service quality in terms of physical quality, interactive quality, and corporate (image) quality. Physical quality is associated with tangible aspects of a service. Interactive quality studies the two-way interaction between a customer and a service provider or the provider's representative, including both automated and animated interactions. Corporate quality is associated with the image attributed to a service provider by its current and potential customers. The main activities of banks are to produce services and services are the main product of banks. The proposed study of our research is to use SERQUAL for one of Iranian banks 
named Maskan. The main objective of this paper is to survey relationship between customer perceptions from service encounter quality and loyalty of customer to organization and employees. According to above mention, authors represent the main hypothesis as:

Main $H$ : there is a positive relationship between customer perceptions from service encounter quality and customer loyalty to organization and employees.

The following sub-hypothesis are studied in this paper,

H1: There is a positive relationship between customer perceptions from service encounter quality and customer satisfaction.

H2: There is a positive relationship between customer perceptions from service encounter quality and customer satisfaction.

H3: There is a positive relationship between customer satisfaction and customer perceptions from quality services.

H4: There is a positive relationship between quality services and customer loyalty to organization.

H5: There is a positive relationship between customer satisfaction and customer loyalty to employees.

H6: There is a positive relationship between customer loyalty to employee and customer loyalty to organization.

\section{Methodology}

Research conceptual model presents critical factors of service encounter quality. After surveying and consulting with specialists and professors, and according to managers and employees of Maskan Bank we consider conceptual model given in Fig. 1. The proposed model considers five SERQUAL components including service encounter quality, service quality, customer satisfaction and customer loyalty and dimensions and indicators are shown in Table 1. For content validity of questionnaire, related academic professors, experts, and specialist and Maskan Bank experts were consulted and they confirmed the feedbacks. For assessing the internal consistency of the questionnaire, Cronbach's Alpha was used that is obtained 0.85, which is well above the minimum required level.

Table 1

Dimensions and indicators

\begin{tabular}{ll}
\hline Dimensions & Indicators \\
\hline service encounter quality & Professional \\
& Courtesy employee \\
& Employee sincerity with customers \\
service quality & Employee competency \\
& Objectivity \\
& Reliability \\
& Guaranty \\
customer satisfaction & Unanimity \\
customer loyalty & $\ldots$ \\
& Customer loyalty to organization \\
\hline
\end{tabular}




\section{Results}

According to demographic data, more than 70 percent of respondents are male. More information is shown in Table 2. Descriptive statistic (frequency, mean, standard deviation.) was shown in Table 2. According to research data from Table 3, the factors of satisfaction, employee loyalty, service encounter quality, service quality and loyalty to organization had the highest scores respectively (3.78, 3.67, 3.60, 3.57 and 3.56) in Maskan Bank.

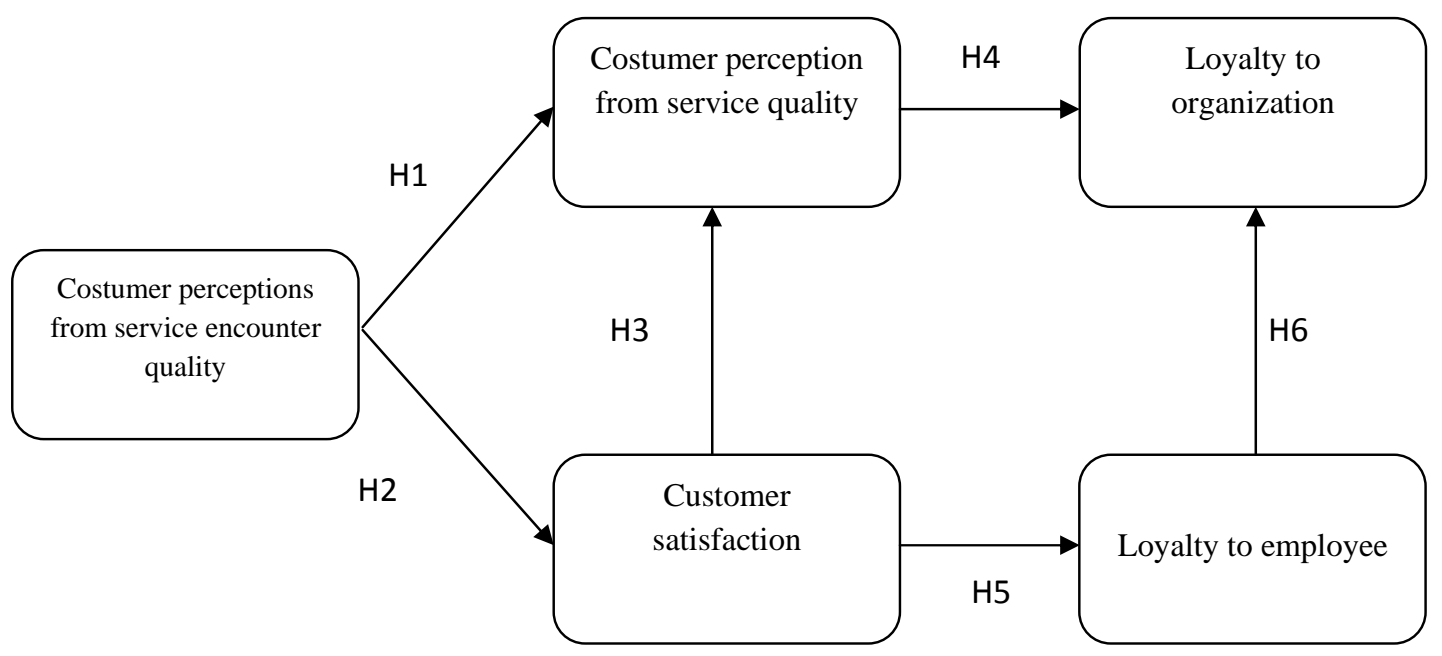

Fig. 1. Research conceptual model

Table 2

Demographic data of population

\begin{tabular}{ccc}
\hline & Number & Percent (\%) \\
\hline & Kind of activity & \\
Export & 13 & 12.7 \\
Business & 32 & 31.4 \\
Administrative & 13 & 12.7 \\
Personal & 44 & 43.1 \\
\hline & Sex & \\
Male & 76 & 74.5 \\
\hline Female & 26 & 25.5 \\
\hline & Education \\
\hline High school & 28 & 27.5 \\
\hline Diploma & 31 & 30.04 \\
\hline Undergraduate & 41 & 40.2 \\
MS./MA & 2 & 2 \\
Ph.D & 0 & 0 \\
\hline
\end{tabular}

As shown in Table 3 commitments of employees received the highest ranking with the mean of 4.3 and knowledge level of employees played the lowest rank with mean rank of 3.59. 
Table 3

Measure of statistic for every variable

\begin{tabular}{|c|c|c|c|c|c|}
\hline Variable & Description & Frequency & Mean & $\begin{array}{l}\text { Standard } \\
\text { Deviation }\end{array}$ & $\begin{array}{l}\text { Coefficient } \\
\text { of variation }\end{array}$ \\
\hline \multirow{6}{*}{$\begin{array}{c}\text { Service } \\
\text { encounter } \\
\text { quality }\end{array}$} & Politely contact of employees & 102 & 4 & 1.062 & 0.265 \\
\hline & Rational and unimposing contact of employees & 102 & 4 & 1.053 & 0.263 \\
\hline & Friendly and sincere contact of employees & 102 & 4.01 & 1.004 & 0.25 \\
\hline & Information presentation & 102 & 3.99 & 1.029 & 0.275 \\
\hline & Professional sufficiency of employees & 102 & 3.99 & 1.048 & 0.262 \\
\hline & Skillful employees & 102 & 4 & 1.019 & 0.25 \\
\hline \multirow{8}{*}{$\begin{array}{l}\text { Service } \\
\text { quality }\end{array}$} & Having physical equipment & 102 & 3.93 & 1.092 & 0.277 \\
\hline & $\begin{array}{l}\text { Conformity of physical equipment with } \\
\text { service kind }\end{array}$ & 102 & 3.97 & 1.057 & 0.395 \\
\hline & Observing time framework in service present & 102 & 3.96 & 1.151 & 0.29 \\
\hline & Sympathetically contact & 102 & 3.98 & 1.062 & 0.4 \\
\hline & Confidentiality & 102 & 3.96 & 1.080 & 0.27 \\
\hline & Respectfully behavior of employees & 102 & 3.98 & 1.043 & 0.262 \\
\hline & Attention to customer & 102 & 4 & 1.043 & 0.26 \\
\hline & Customer needs detection & 102 & 3.97 & 1.047 & 0.263 \\
\hline \multirow{3}{*}{$\begin{array}{l}\text { Customer } \\
\text { satisfaction }\end{array}$} & Knowledge level of employees & 102 & 3.69 & 1.098 & 0.297 \\
\hline & Individually commitment of employees & 102 & 4 & 1.038 & 0.259 \\
\hline & Presenting of useful information by employees & 102 & 4 & 1.024 & 0.256 \\
\hline \multirow{3}{*}{$\begin{array}{l}\text { Loyalty to } \\
\text { organization }\end{array}$} & Feeling pride in service using & 102 & 4 & 1.048 & 0.262 \\
\hline & Encouraging to repeat service receipt & 102 & 3.96 & 1.070 & 0.27 \\
\hline & To preference the organization & 102 & 4 & 1.034 & 0.258 \\
\hline \multirow{3}{*}{$\begin{array}{l}\text { Loyalty to } \\
\text { employees }\end{array}$} & To glad in working with employees & 102 & 3.74 & 1.024 & 0.273 \\
\hline & To be sensitive on employees' destiny & 102 & 3.99 & 1.076 & 0.269 \\
\hline & Having same expectations with employees & 102 & 3.97 & 1.103 & 0.277 \\
\hline
\end{tabular}

Table 4

Mean distribution of opinions of respondents to the dimensions of service encounter quality

\begin{tabular}{cll}
\hline Rank & Dimension & Amplitude \\
\hline 1 & Customer satisfaction & 3.78 \\
2 & Loyalty to employees & 3.67 \\
3 & Service encounter quality & 3.6 \\
4 & Service quality & 3.57 \\
5 & Loyalty to organization & 3.56 \\
\hline
\end{tabular}

Mean distribution of opinions of respondents to dimensions of service encounter quality and questions of research in turn are shown in Table 4 and Table 5. In order to determine the relationship between research variables, Pearson correlation was utilized.

As indicated in Table 6 there was a direct and significant relationship between customer service satisfaction and customer perceptions from service encounter quality ( $\mathrm{r}=0.81)$, and customer perceptions from service encounter quality $(\mathrm{r}=0.41)$, and customer perceptions from quality services (0.37). In addition, there was a direct and significant relationship between customer loyalty to organization and quality services $(r=.73)$ and customer satisfaction $(r=.31)$ and customer loyalty to employee ( $r=.73)$. 
Table 5

Mean distribution of opinions of respondents to questions of research

\begin{tabular}{cclc}
\hline Rank & No. of question & \multicolumn{1}{c}{ Description } & Score \\
\hline 1 & 21 & Individually commitment of employees & 4.3 \\
\hline 2 & 6 & Politely contact of employees & 3.77 \\
3 & 26 & To glad in working with employees & 3.74 \\
4 & 28 & Having same expectations with employees & 3.74 \\
\hline 5 & 15 & Sympathetically contact & 3.64 \\
6 & 14 & Observing time framework in service present & 3.62 \\
\hline 7 & 19 & Customer needs detection & 3.61 \\
\hline 8 & 7 & Rational and unimposing contact of employees & 3.59 \\
\hline 9 & 25 & To preference the organization & 3.59 \\
10 & 10 & Professional sufficiency of employees & 3.58 \\
11 & 18 & Attention to customer & 3.58 \\
\hline 12 & 8 & Friendly and sincere contact of employees & 3.56 \\
\hline 13 & 22 & Presenting of useful information by employees & 3.56 \\
14 & 23 & Feeling pride in service using & 3.56 \\
\hline 15 & 16 & confidentiality & 3.55 \\
16 & 17 & Respectfully behavior of employees & 3.55 \\
\hline 17 & 24 & Encouraging to repeat service receipt & 3.55 \\
\hline 18 & 27 & To be sensitive on employees' destiny & 3.55 \\
\hline 19 & 9 & Information presentation & 3.54 \\
\hline 20 & 11 & Skillful employees & 3.53 \\
\hline 21 & 13 & Conformity of physical equipment with service kind & 3.51 \\
\hline 22 & 12 & Having physical equipment & 3.5 \\
\hline 23 & 20 & Knowledge level of employees & 3.49 \\
\hline
\end{tabular}

\section{Conclusion}

In this paper, we have presented an empirical SERQUAL analysis for a real-world case study of banking industry in Iran. The results of the survey indicated that service quality systems, customer satisfaction were the most desirable factors based on what customers think. In addition, response to customers and loyalty to employees, service encounter quality, service and loyalty to organization, arrangements are in the next levels with the ranking of 3.56, 3.57, 3.6, 3.67, 3.78, respectively. Based on the feedbacks we received from the customers, loyalty to organization has become as the most undesirable factor. Note that all factors were well above 3 and all factors were in desirable level. Employee responsibility was also selected as the most desirable factor followed by other factors including employee impact politely, same employee expectations, the sense of satisfaction to work with employees and impact compassionately.

According to the results, question number 1 has upper than 4, in the other hand it had desirable between high and too high. Question number 22 had score upper than 3 and less than 4, in the other hand it has desirable between average and high. Table 6 summarizes the results of our survey and as we have found a positive relationship between customer perceptions from service encounter quality and customer satisfaction, a positive relationship between customer perceptions from service encounter quality and customer satisfaction, a positive relationship between customer satisfaction and customer perceptions from quality services, a positive relationship between quality services and customer loyalty to organization, a positive relationship between customer satisfaction and customer 
loyalty to employees and a positive relationship between customer loyalty to employee and customer loyalty to organization.

Table 6

Summary of research results of hypotheses

\begin{tabular}{lccc}
\multicolumn{1}{c}{ Hypothesis } & $\begin{array}{c}\text { Level of } \\
\text { confidence }\end{array}$ & $\begin{array}{c}\text { Coefficient } \\
\text { of correlation }\end{array}$ & Results \\
\hline $\begin{array}{l}\text { H1: There is positive relationship between customer } \\
\text { perceptions from service encounter quality and customer }\end{array}$ & 0.95 & 0.808 & accepted \\
$\begin{array}{l}\text { satisfaction } \\
\text { H2: there is positive relationship between customer } \\
\text { perceptions from service encounter quality and customer } \\
\text { satisfaction }\end{array}$ & 0.95 & 0.41 & accepted \\
$\begin{array}{l}\text { H3: there is positive relationship between customer } \\
\text { satisfaction and customer perceptions from quality services }\end{array}$ & 0.95 & 0.368 & accepted \\
$\begin{array}{l}\text { H4: there is positive relationship between quality services } \\
\text { and customer loyalty to organization. }\end{array}$ & 0.95 & 0.726 & accepted \\
$\begin{array}{l}\text { H5: there is positive relationship between customer } \\
\text { satisfaction and customer loyalty to employees }\end{array}$ & 0.95 & 0.311 & accepted \\
$\begin{array}{l}\text { H6: there is positive relationship between customer loyalty } \\
\text { to employee and customer loyalty to organization }\end{array}$ & 0.95 & 0.728 & accepted \\
\hline
\end{tabular}

\subsection{Suggestions for future works}

Service quality is a potential context for further researches and experts can perform many surveys to improve level of this issue. Authors suggest areas that can study in future. For example, organizational profit, employee satisfaction, productivity, effectiveness and so on can be a list of variations that analyze their relationships with organization service quality.

\section{Acknowledgment}

This paper was financially supported by Islamic Azad University and the authors would like to thank them for their support. The authors also grateful for constructive comments on earlier version of this work, which improved the quality of the paper.

\section{References}

Au, N, Ngai, E. W. T., \& Cheng, T. C. E. (2008). Extending the understanding of end user information systems satisfaction formation: An equitable needs fulfillment model approach. MIS Quarterly, 32(1), 43-66.

Berry, L.L., Zeithaml, V.A., \& Parasuraman, A. (1985). Quality comes in services, too. Business Horizon, 28, 44-52.

Brady, M.K. and Cronin, J.J. Jr. (2001). Some new thoughts on conceptualizing perceived service quality: a hierarchical approach. Journal of Marketing, 65 (3), 34-49.

Choi, J., Seol, H., Lee, S., Cho, H., \& Park, Y. (2008). Customer satisfaction factors of mobile commerce in Korea. Internet Research, 18(3), 313-335.

Clarke, K. (2001). What price on loyalty when a brand switch is just a click away? Qualitative Market Research: An International Journal, 4(3), 160-168.

Curry, A., \& Sinclair, E. (2002). Assessing the quality of physiotherapy services using SERVQUAL. International Journal of Health Care Quality Assurance, 15 (4/5), 197-205. 
Deng, Z., Lu, Y., Wei, K.K., \& Zhang, J. (2010). Understanding customer satisfaction and loyalty: An empirical study of mobile instant messages in China. International Journal of Information Management, 30 (4), 289-300.

Edvardsson, B. (1998). Service quality improvement. Managing Service Quality, 8 (2), 142-149.

Eggert, A., \& Ulaga,W. (2002). Customer perceived value:Asubstitute for satisfaction in business markets. Journal of Business \& Industrial Marketing, 17(2-3), 107- 118.

Fornell, C. (1992). A national customer satisfaction barometer: The Swedish experience. Journal of Marketing, 56(1), 6-12.

Gabbie, O., \& O’Neill, M. (1997). SERVQUAL and the Northern Ireland hotel sector: a comparative analysis - part 2. Managing Service Quality, 7 (1), 43-49.

Ghobadian, A., Speller, S., \& Jones, M. (1994). Service quality: concepts and models. International Journal of Quality \& Reliability Management, 11 (9), 43-66.

Gronroos, C. (1982). Strategic Management and Marketing in Service Sector, Marketing Science Institute, Cambridge, MA.

Gronroos, C. (1990). Service Management and Marketing, Lexington Books, Lexington, MA.

Harvey, J. (1998). Service quality: a tutorial. Journal of Operations Management, 16 (5), 583-97.

Kang, G., \& James, J. (2004). Service quality dimensions: an examination of Gronroos's service quality model. Managing Service Quality, 14 (4), 266-277.

Kang, G. (2006). The hierarchical structure of service quality: integration of technical and functional quality. Managing Service Quality, 16 (1), 37-50.

Karatepe, O.M., Yavas, U., \& Babakus, E. (2005). Measuring service quality of banks: Scale development and validation. Journal of Retailing and Consumer, Services 12 (5) 373-383.

lehtinen, J.R., \& lehtinen, U. (1982). Service quality: a study of quality dimensions”, unpublished Working Paper, Service Management Institute, Helsinki.

Liao, C., Palvia, P., \& Chen, J.-L. (2009). Information technology adoption behavior life cycle: Toward a technology continuance theory (TCT). International Journal of Information Management, 29(4), 309-320.

Meredith, J.R., \& Shafer, S.M. (2002). Operations Management for MBAs, $2^{\text {nd }}$ ed., John Wiley \& Sons, New York, NY.

Mihelis, G., Grigoroudis, E., Siskos, Y., Politis, Y., \& Malandrakis, Y. (2001). Customer satisfaction measurement in the private bank sector. European Journal of Operational Research, 130 (2) 347360

Ninichuck, B. (2001). Service quality is the key to good business. Pest Control, 69 (9), 12-13.

Oliver, R. L. 1981. Measurement and evaluation of satisfaction processes in retail settings. Journal of Retailing, 57(3), 25-48.

Oliver, R.L. (1997). Satisfaction: A Behavioral Perspective on the Consumer. McGraw-Hill, New York, NY.

Parasuraman, A., Zeithaml, V.A., \& Berry, L.L. (1985). A conceptual model of service quality and its implications for future research. Journal of Marketing, 49(Fall), 41-50.

Parasuraman, A., Zeithaml, V.A. \& Berry, L.L. (1988). SERVQUAL: a multiple-item scale for measuring consumer perceptions of service quality. Journal of Retailing, 64, 12-40.

Saleh, F., \& Ryan, C. (1991). Analyzing service quality in the hospitality industry using the SERVQUAL model. The Service Industries Journal, 11(3), 324-45.

Stevenson, W., 2002, Production and Operations Management, 7th ed., McGraw-Hill, New York, NY.

Sultan, F., \& Simpson, M.C. (2000). International service variants: airline passenger expectations and perceptions of service quality. The Journal of Services Marketing, 14 (3), 188-216.

van der Wal, R.W.E., Pampallis, A., \& Bond, C. (2002). Service quality in a cellular telecommunications company: a South African experience. Managing Service Quality, 12 (5), 233-6. 
Walsh, G., Dinnie, K., \& Wiedmann, K.-P. (2006). How do corporate reputation and customer satisfaction impact customer defection? A study of private energy customers in Germany. Journal of Services Marketing, 20(6), 412-420.

Wisniewski, M. (2001). Using SERVQUAL to assess customer satisfaction with public sector services. Managing Service Quality, 11 (6), 380-91.

Yazdanpanah, A.A., \& Gazor, H. (2012). Detecting success factors of electronic customer relationship management (e_CRM) system to establish an appropriate model in police call Centre of Iran. Management Science Letters, Vol. 2(1), 339-350.

Zeithaml, V.A., \& Bitner, M.J. (2000). Services Marketing, McGraw-Hill, New York, NY. 